Portland State University

PDXScholar

Urban Studies and Planning Faculty

Nohad A. Toulan School of Urban Studies and

Publications and Presentations

Planning

$2-1-2020$

\title{
Adaptive Injustice: Responsibility to Act in the Plastics Economy
}

Katie Conlon

Portland State University, conlon@pdx.edu

Follow this and additional works at: https://pdxscholar.library.pdx.edu/usp_fac

Part of the Environmental Studies Commons, and the Urban Studies and Planning Commons

Let us know how access to this document benefits you.

\section{Citation Details}

Conlon, K. (2020). Adaptive injustice: Responsibility to act in the plastics economy. Resources, Conservation and Recycling, 153, 104563.

This Pre-Print is brought to you for free and open access. It has been accepted for inclusion in Urban Studies and Planning Faculty Publications and Presentations by an authorized administrator of PDXScholar. Please contact us if we can make this document more accessible: pdxscholar@pdx.edu. 
Adaptive Injustice: Responsibility to act in the Plastics Economy

How can plastic material be reduced, reused, repurposed, or salvaged so it is kept out of rivers, oceans and ecosystems in general? Social awareness about the impacts of plastic pollution is growing, and creative, social solutions to the 'plastic menace' are popping up globally. Every day, one can read about the latest, innovative method for managing plastic waste at the local level: plastic PET bottles stuffed with plastic-film food wrappers to make 'ecobricks;' paving roads with plastic waste; making yoga-wear out of marine plastic pollution; weaving plastic into tote bags; using a 3D printer to make plastic into products for a community social enterprise; turning plastic bottles into rafts, or flip-flops into colorful sculptures; the list goes on and on. Solutions such as these for plastic waste receive much attention and applause. However, are these actual solutions, or more partial-fixes for managing the ever-increasing onslaught of plastic waste?

Ironically, creative reuse of plastics ultimately creates new avenues and markets for using plastic, and ties more livelihoods to the plastic economy. There is a contradictory dynamic between the efforts of well-meaning social enterprises to minimize plastics impacts vs. the increasing forward march of the plastics production industry. This dynamic would benefit from a term to allow for these processes to be more readily identified, as currently these two sectors of society operate, for the most part, in different spheres. An applicable term is adaptive injustice: those who find ways to adapt to changing social realities, whether forced or voluntary, are not those who are responsible for the negative changes to which they are adapting. Specifically, it is an adaptive injustice to expect communities to figure out what to do with continual flow of plastics into the economy.

There is no place for plastics to go, they are an inorganic product designed for durability and thus their impact perpetuates for centuries - almost every piece of plastic ever made is still around today (Geyer et al., 2017). Globally, plastic waste is expected to increase, from 6.3 billion metric tons in 2015 to a projected 26 billion tons by 2050 (ibid). And yet, the use of this material perpetuates, as plastics continue to be produced into more and more products. Microplastics, like the nuclear fallout from the plastics industry, are now found in soil samples, river samples, food samples, and ocean samples around the globe, even in the most remote settings. The onus of environmental degradation from plastics products is given to communities to bear. Producers of plastics continue to push for market expansion and the perpetuation of cheap, single-use, packaging, in a race to expand their business. Imagine how markets would change if companies had to account for every piece of plastic they ever made. The burden of adaptation would switch and companies would bear the costs of their packaging, and not citizens and local governments. 
Undoubtedly, it is inspiring to see the concerned efforts of individuals and communities around the globe who rally for cleanups and the creative reuse of plastics. However, the root of the plastic waste problem needs to be addressed: the extraction and production. Local initiatives that skip over deeper evaluation of the economic processes that create accumulating plastic wastes might actually prolong the problem. When responsibility for the problem is taken up by individuals, or communities, this deflects the burden of responsibility away from the producers. Essentially, it is the upstream extraction of natural resources to create plastics and the increasing production of plastic products that is the problem; solve this, and the downstream effects of plastics go away.

If plastic-making processes are not unpacked as the reason we have a plastic problem to begin with, then we will not, nor ever, 'solve' the ocean plastic pollution problem. Whether the measurement of plastics inputs comes from the rivers or from shoreline communities, fundamentally it is not a question of 'mismanagement,' but about reducing this material in our global supply chains. Plastics have been shown to cause harm to health at all stages of their lifecycle, extraction, production, transportation, use and disposal (CIEL, 2019). As long as we continue to allow the production of plastic food packaging and single-use, the problem will persist. Given current recycling statistics - globally only $2 \%$ of material is recycled one to one, $8 \%$ is downcycled, $4 \%$ is lost in recycling processes, and the rest is not sorted and collected (World Economic Forum, 2016) - one can argue that even material designed to be recycled is a problem unless there are guaranteed infrastructure and handling processes. In this case, the ability to recycle would need to be redefined as 'having the capacity to process recyclable material within 150 miles from collection.' This would mean urban centers would need to have the capacity to recycle the materials they use within the region. Without such delineation, urban recycling systems are: not being responsive to the flow and types of materials being thrown away; lacking transparency and potentially in violation of social and/or environmental justice; accruing too many transportation carbon miles; and potentially can encounter shocks such as what transpired in the US after China enacted the National Sword.

\section{Producers get the profit; society and the environment get the externality.}

Plastics are the cornerstone on which current economic processes rely; they are the "lubricant of globalization" (Moore, 2014). A brief foyer into publications such as Plastics Business Mag, Plastics News, or a search of 'Plastic Market Trends,' and one will find optimistic projections of how plastic can continue to lubricate trade. Future expansion, new customers and opportunities, and increased sales of plastics, the trends are looking up in the coming years for this global, billion-dollar plastics business. The plastic packaging market accrued $\$ 300.86$ billion revenue in 2016 and is projected to rise to $\$ 480.97$ billion by 2025 . Plastics producers are similarly excited 
about the new market growth for the plastics economy allowed by the fracking boom. This industry pride seems to fly in the face of contemporary environmental concerns. Yet, from the perspective of the plastic industry and the companies that rely on these materials, there is no slowing down production, and the future trajectory is prosperous.

Shouldn't the earth's bottom line come before the bottom line of businesses?

Producers still operate within a model that expects local governments and taxpayers to foot the bill for the disposal of their packaging. Adaptation to the proliferation of plastics should not the responsibility externalized to individuals, communities, and the environment. Designing plastics out of the system should be the responsibility of businesses, the upstream source, the entities that make and rely on these products for the backbone of their sales. One example is the Alliance to End Plastic Waste (AEPW). This alliance is comprised of companies that make their earnings from plastics and oil related industries, and the alliance proposes solutions to plastic waste - the problems of the material they create -yet none of these solutions involve curtailing their plastic production business model. Similarly, practices like redesigning plastic bottles with lids that use less plastics (when what is really needed is to get rid of the bottle to begin with), is another example of business going only as far as suits their bottom line, and not addressing actual environmental needs. These micro-changes are just stalling, and in the meantime impacts of plastic pollution continue to accumulate.

It's time to retire this 'privatizing profits, socializing costs' model.

In the current model, once plastic is purchased from the producer, it is up to society to dispose of or find another purpose for, such as: use tax dollars to manage collection and build recycling facilities; upcycle; reuse; recraft; repurpose, etc. But it's basically a global game of 52-card pickup, to continue to make plastic and then wait to see how communities will deal with it. Humans are creative and adaptable beings, and will find innovative ways to reuse and repurpose plastics in a multiplicity of ways around the globe; yet, it is a gross oversight to continue to let this lack of plastics minimization and responsible materials use at the top, or this adaptive injustice, dictate the environmental and social harms that result from the plastics economy.

In the global south, adaptive injustice is starkly apparent as most urban areas lack sufficient waste options for the increasing amount of waste generated (Hoornweg and Bhanda-Tata, 2012), and rising consumption of single-use plastic packaging only magnifies this problem. Even if waste is collected, open dumping or incineration are often the default management techniques both methods that do not consider resource conservation, materials recovery, and long-term consequences of continued consumption patterns. In the case of the Philippines for instance, a sobering 163 million plastic sachets, 48 million shopping bags, and 45 million thin film bags are 
used in the nation on a daily basis (GAIA, 2019). There is no 'away' for this material to go, and the visuals of this injustice - the externalities of plastic waste - are strewn about on streets, in waterways, and on beaches.

Whether a multinational or a local manufacturer, it is both a social and ecological injustice to make products without considering their consequences. In order to stop these processes of plastic production from scouring the globe, we need corporations to take responsibility for the full lifecycle of their products and packaging. This means redesigning and reimagining how goods can be packaged and not letting communities be burdened with the bill of waste material. Just as society had to be taught to use plastics in the 1950s, we can collectively relearn how to revalue the materials we use and opt for materials that 'do not harm.' The whole concept of packaging should evolve to be synonymous with 'second life' and full lifecycle accountability. Responsible materials use is not just a matter of economic choice or preference, but a social and environmental urgency.

Center for International Environmental Law (CIEL). (2019). Plastic \& Health: The Hidden Costs of a Plastic Planet. CIEL. Retrieved on July 13, 2019, from: https://www.ciel.org/reports/plastic-health-the-hidden-costs-of-a-plastic-planet-february-2019/

GAIA. (2019). Plastics Exposed: How Waste Assessments and Brand Audits are Helping Philippine Cities Fight Plastic Pollution. GAIA. Retrieved on July 11, 2019, from: https://www.no-burn.org/wp-content/uploads/PlasticsExposed-3.pdf

Geyer, R., Jambeck, J. R., \& Law, K. L. (2017). Production, use, and fate of all plastics ever made. Science advances, 3(7), e1700782.

Moore, Capt. C.J. (August 25, 2014). Choking the Oceans with Plastic (Opinion). New York Times. Retrieved on July 11, 2019, from: https://www.nytimes.com/2014/08/26/opinion/choking-the-oceans-with-plastic.html

World Economic Forum, Ellen MacArthur Foundation, and McKinsey and Company. (2016) A New Plastics Economy:

Rethinking the Future of Plastics. Retrieved on April 24, 2019,

from: https://www.ellenmacarthurfoundation.org/assets/downloads/Foundation New-Plastics-Economy 5.jpg 